\title{
Targeting the CYP2B1/Cyclophosphamide Suicide System to Fibroblast Growth Factor Receptors Results in a Potent Antitumoral Response in Pancreatic Cancer Models
}

\author{
MERITXELL HUCH, ${ }^{1}$ DANIEL ABATE-DAGA, ${ }^{1}$ JOSEP MARIA ROIG,${ }^{2}$ JUAN RAMON GONZÁLEZ, ${ }^{1}$ \\ JOAN FABREGAT, ${ }^{3}$ BARBARA SOSNOWSKI, ${ }^{4}$ ADELA MAZO,${ }^{2}$ and CRISTINA FILLAT ${ }^{1}$
}

\begin{abstract}
The CYP2B1/cyclophosphamide (CPA) suicide gene therapy approach has been shown to be highly promising in clinical trials for the treatment of pancreatic cancer. However, delivering the therapeutic gene to a sufficient number of tumor cells able to trigger a complete response remains a challenge. Target-specific delivery of adenovirus to fibroblast growth factor receptors (FGFRs) has been obtained in a variety of tumor models and has been shown to highly increase transduction efficiency. In the present paper we have tested the therapeutic outcome of retargeting the adenoviral vector, Ad-CYP2B1, to FGFRs, using an FGF2-Fab' conjugate, in pancreatic cancer models. First, we show a heterogeneous subcellular distribution of overexpressed FGFR-1 in pancreatic cancer cells. Higher transduction efficiency was observed in five of the six cell lines studied after FGF2-AdGFPLuc infection. Interestingly, an association between FGFR-1 membrane cell expression and viral entry was found. Moreover, tumors injected with FGF2-AdGFPLuc showed enhanced and persistent transgene expression. Importantly, we demonstrate the relevant enhanced cytotoxic effect of the FGF2-Ad-CYP2B1/CPA system in four of the six cell lines studied. Moreover, retargeting Ad-CYP2B1/CPA to FGFRs resulted in a potent antitumoral effect and in an increased survival rate, in two human pancreatic xenograft models. Thus, our results indicate that redirecting adenoviruses to FGFRs highly increases the potency of the suicide system CYP2B1/CPA. Consequently, it may constitute a promising approach to the treatment of patients with pancreatic tumors, in which a high proportion of FGF receptors precisely localize to the plasma membrane.
\end{abstract}

\section{OVERVIEW SUMMARY}

Bioactivation of the CYP2B1 gene by ifosfamide after local injection of microencapsulated CYP2B1-producing cells has shown promising results in the treatment of inoperable pancreatic carcinoma, suggesting that this system is a potent inducer of cell death. In the present work we aimed to study CYB2B1/cyclophosphamide (CPA) antitumoral activity when delivered by a highly efficient gene transfer system based on retargeting adenoviruses to fibroblast growth factor receptors (FGFRs). We showed that although there was some degree of heterogeneity, pancreatic tumor cells highly expressed FGFRs at the plasma membrane. Moreover, retargeting adenovirus to FGFRs enhanced adenoviral trans- duction and increased CYP2B1/CPA cytotoxicity. Importantly, intratumoral delivery of the Ad-CYP2B1 through FGFRs in combination with cyclophosphamide resulted in a potent antitumoral effect and a significant increase in the survival rate when assessed in two independent xenograft models, indicating the efficient response of pancreatic tumors to this type of therapy.

\section{INTRODUCTION}

$\mathbf{P}$ ANCREATIC DUCTAL ADENOCARCINOMA remains a malignancy with no satisfactory treatment. Only in a few selected cases does surgical resection offer the possibility of a cure.

\footnotetext{
${ }^{1}$ Programa Gens i Malaltia, Centre de Regulació Genòmica-Universitat Pompeu Fabra, 08003 Barcelona, Spain.

${ }^{2}$ Departament de Bioquímica i Biologia Molecular, Universitat de Barcelona, 08028 Barcelona, Spain.

${ }^{3}$ Servei de Cirurgia General i Digestiva, Hospital Universitari de Bellvitge, L'Hospitalet de Llobregat, 08907 Barcelona, Spain.

${ }^{4}$ Tissue Repair Company, San Diego, CA 92121.
} 
However, most patients are not eligible for this type of treatment, and therefore undergo a variety of chemotherapeutic regimens. Although an increase in the time free from recurrence has been reported with such chemotherapies, there is no overall improvement in mean survival rate (Abrams, 2003).

Gene-directed enzyme prodrug therapy (GDEPT), which uses cytochrome $P-450$ (CYP) enzymes to activate established anticancer prodrugs, such as cyclophosphamide (CPA) and its isomer ifosfamide, was first described to have antitumoral activity in a brain tumor model (Wei et al., 1994, 1995). Interestingly, it has also been shown to be a promising therapeutic approach for pancreatic cancer both in mouse models and in clinical studies (Lohr et al., 1998; Muller et al., 1999; Lohr et al., 2001; Carrio et al., 2002). CPA and ifosfamide are alkylating prodrugs that covalently cross-link DNA in a cell cycleindependent manner, triggering apoptotic cell death in the case of CPA (Schwartz and Waxman, 2001), and either apoptosis or necrosis in the case of ifosfamide (Karle et al., 2001; Schwartz and Waxman, 2001). The efficacy of P-450 GDEPT has been enhanced by highly diverse approaches, ranging from increasing the bystander effect through expression of antiapoptotic factor p35 (Schwartz et al., 2002) to combination with several different strategies, such as with other suicide approaches (Aghi et al., 1999; Carrio et al., 2002), with tumor suppressor genes (Mercade et al., 2001), with viral oncolysis and chemosensitization (Chase et al., 1998; Tyminski et al., 2005), and with replicating adenovirus that promotes the spreading of replication-defective Adeno-P450 (Jounaidi and Waxman, 2004). Another approach to increase the efficacy of CYP2B1/CPA treatment has been the intratumoral injection of polymers impregnated with CPA, resulting in an enhanced tumor concentration of active metabolites (Ichikawa et al., 2001).

Adenoviruses are attractive vectors for gene delivery and it has been clearly established that entry of the most commonly used adenoviral vector, serotype 5 (Ad5), into the cell starts by interaction of the C-terminal knob viral fiber domain and the primary cellular receptor, the coxsackievirus-adenovirus receptor (CAR). Although CAR is expressed on most normal epithelial cells, data suggest that CAR expression may be highly variable in tumors, resulting in resistance to Ad5 infection ( $\mathrm{Li}$ et al., 1999; Anders et al., 2003). Consequently, modification to redirect adenoviral tropism to receptors highly expressed in cancer cells might improve tumor transduction, leading to an increased antitumoral effect.

Fibroblast growth factor receptors (FGFRs) have already been demonstrated to be overexpressed in human pancreatic adenocarcinomas (Kobrin et al., 1993; Leung et al., 1994; Ohta et al., 1995; Yamazaki et al., 1997). Retargeting adenovirus to FGFRs through basic fibroblast growth factor-2 (FGF2) has been shown to enhance cell transduction, both in vivo and in vitro, in various tumor models (Sosnowski et al., 1996; Goldman et al., 1997; Rancourt et al., 1998; Gu et al., 1999; Wang et al., 2005). In pancreatic cancer, it has been shown that targeting AdTK/GCV (adenoviral vector carrying the herpes simplex virus thymidine kinase gene/ganciclovir) enhances the cytotoxic effect of ganciclovir in vitro, although in only a limited number of pancreatic cell lines (Kleeff et al., 2002).

In the present study our aim was to enhance CYP2B1/CPA cytotoxic activity in pancreatic tumors by facilitating gene delivery. We report that targeting adenovirus to plasma membrane fibroblast growth factor receptors enhances the efficiency of adenovirus-mediated transduction of pancreatic tumor cells. Moreover, increased expression that persists for a longer period of time is achieved in vivo with the redirected virus. Interestingly, we demonstrate that, by redirecting Ad-CYP2B1 to FGF receptors, enhanced cytotoxic efficacy of the CYP2B1/CPA suicide approach is obtained, both in cell culture and in vivo in two independent human xenograft models.

\section{MATERIALS AND METHODS}

\section{Cell lines and cell culture}

Human pancreatic adenocarcinoma cell lines PANC-1 and BxPC-3 were obtained from the American Type Culture Collection (ATCC, Manassas, VA). The RWP-1 pancreatic cancer cell line was kindly provided by F.X. Real (Institut Municipal d'Investigació Mèdica, Barcelona, Spain) and NP-31, NP-9, and NP-18 cells were derived from human pancreatic adenocarcinoma biopsies and perpetuated as xenografts in nude mice (Villanueva et al., 1998). Cells were maintained in Dulbecco's modified Eagle's medium (DMEM) (PANC-1, BxPC-3, RWP-1, and NP-9) or in RPMI 1640 medium (NP-18 and NP-31), supplemented with $10 \%$ fetal bovine serum (FBS) and antibiotics, at $37^{\circ} \mathrm{C}$ in a humidified atmosphere containing $5 \% \mathrm{CO}_{2}$.

\section{Tissues}

Thirty pancreatic ductal adenocarcinomas were studied. Surgical specimens were obtained as formalin-fixed paraffin-embedded tissues from patients undergoing surgical resection of pancreatic adenocarcinoma from Hospital Universitari de Bellvitge (Barcelona, Spain) in the period between 1996 and 2001. Characteristics of patients were as follows: age, 64 years (range, 40-95 years); sex, 18 male and 12 female; stage: T2, 1; T3, 27; T4, 2; N0, 12; N1, 18; M, 28; M1, 2. All samples were collected under institutional review board-approved protocols and informed consent was obtained from each patient.

\section{Immunofluorescence and confocal analysis}

Cells were grown at a density of $3 \times 10^{5}$ cells per well and fixed in $4 \%$ paraformaldehyde. The cells were then incubated with rabbit anti-FGFR-1 polyclonal antibody (diluted 1:200; Santa Cruz Biotechnology, Santa Cruz, CA) overnight at $4^{\circ} \mathrm{C}$, rinsed in phosphate-buffered saline (PBS) $-0.3 \%$ Triton $\mathrm{X}-100$, and incubated for $1 \mathrm{hr}$ with a goat anti-rabbit secondary antibody conjugated to Alexa 488 (diluted 1:400; Invitrogen Molecular Probes, Leiden, The Netherlands). The cells were washed thoroughly and stained with TO-PRO-3 iodide (Invitrogen Molecular Probes, Eugene, OR) as a nuclear marker.

Immunofluorescent staining was analyzed with an inverted Leica TCS SP2 confocal scanning laser microscope (Leica Microsystems, Wetzlar, Germany) and an HCX PL Apo ×40/1.25 NA Oil Ph3 CS objective. Double immunofluorescence images were acquired in a sequential mode, using the 488-nm line of the argon laser (Alexa 488) and a 633-nm helium-neon laser (TO-PRO-3 iodide). Images corresponding to six optical sections, with a sequential $z$ step (depth of $1.06-1.10 \mu \mathrm{m}$, depending on the cell type) and an $x / y$ resolution of $0.18 \mu \mathrm{m}$, were 
captured from the lowest plane to the highest plane with Leica Confocal Software (LCS; Leica Microsystems). Laser intensity and detector sensitivity were set for the most intensely stained sample, and all other pictures were captured with the same settings. Omission of the primary antibody resulted in no signal. Images were processed with Adobe Photoshop 6.0 software (Adobe, San Jose, CA).

\section{Immunohistochemistry}

Formalin-fixed and paraffin-embedded samples were prepared from human pancreatic adenocarcinoma tissues and from xenografted tumors. Sections ( $5 \mu \mathrm{m}$ thick) were deparaffinized, rehydrated, and treated with $10 \%$ normal goat serum. When stated, the sections were incubated with either a rabbit antiFGFR-1 polyclonal antibody (diluted 1:200; Santa Cruz Biotechnology) or a goat anti-rat CYP2B1 polyclonal antibody (diluted 1:100; Daiichi Pure Chemicals, Tokyo, Japan), for 72 $\mathrm{hr}$ at $4^{\circ} \mathrm{C}$. Bound antibodies were detected with universal biotinylated secondary antibody and streptavidin-peroxidase complex, in accordance with the supplier's instructions (Universal LSAB +; Dako Diagnostics, Zug, Switzerland). Diaminobenzidine was used as substrate. Sections were counterstained with Mayer's hematoxylin. All sections were examined with a Leica DMR microscope (Leica Microsystems). Images were captured with a digital camera (Leica DC 500; Leica Microsystems) and processed with Leica Image Manager (IM) and Adobe Photoshop software. Omission of primary antibodies resulted in the absence of any immunoreactivity.

\section{Recombinant adenoviruses and FGF2-conjugated adenoviruses}

Replication-defective adenovirus AdGFPLuc (Alemany and Curiel, 2001), expressing green fluorescent protein (GFP) and firefly luciferase (Luc) under the control of the cytomegalovirus (CMV) promoter, was kindly provided by R. Alemany (Institut Català d'Oncologia, Barcelona, Spain). Ad-CYP2B1 has been previously described (Mercade et al., 2001); it is an E1deleted Ad5 vector that expresses the rat cytochrome $p 4502 B 1$ gene under the control of the CMV promoter. Recombinant adenoviral vectors were propagated in the adenovirus-packaging cell line HEK293 and purified by cesium chloride banding according to standard techniques (Becker et al., 1994).

The FGF2-Fab' molecule consists of a neutralizing monoclonal antibody directed against the Ad5 knob region and conjugated with a modified FGF2 as described (McDonald et al., 1996; Sosnowski et al., 1996). To obtain FGF2-AdGFPLuc and FGF2-Ad-CYP2B1 viruses, FGF2-Fab' molecules were bound to the corresponding adenovirus carrying either the GFPLuc construct (AdGFPLuc) or the $C Y P 2 B 1$ gene (Ad-CYP2B1) at a 1:50 ratio (virus:FGF2-Fab').

\section{In vitro transduction efficiency studies}

To determine transduction efficiency, GFP expression was visualized with an inverted Leica DM IRB fluorescence microscope, $72 \mathrm{hr}$ postinfection. Images were captured with a Leica DC 500 digital camera and processed with Leica IM and Adobe Photoshop. To quantify transduction efficiency, cells were lysed and assayed for luciferase activity according to the manufacturer's instructions (Luciferase Assay System; Promega, Madison, WI). Luciferase activity was measured in an Orion microplate luminometer (Berthold Detection Systems, Pforzheim, Germany) and normalized to total protein levels. Protein concentration was determined with a bicinchoninic acid (BCA) protein assay kit (Pierce Biotechnology, Rockford, IL).

\section{Dose-response analysis}

Cell viability was measured and quantified in PANC-1, BxPC-3, NP-31, NP-9, RWP-1, and NP-18 pancreatic cancer cells by a colorimetric assay system based on the tretrazolium salt 3-(4,5-dimethylthiazol-2-yl)-2,5-diphenyl tetrazolium bromide (MTT; Roche Molecular Biochemicals, Mannheim, Germany), in accordance with the manufacturer's instructions. Results were expressed as the percent absorbance determined in treated wells relative to that in untreated wells. The $50 \%$ infective dose $\left(\mathrm{ID}_{50}\right)$ was defined as the multiplicity of infection (MOI) resulting in 50\% loss of cell viability relative to untreated cells, and was estimated from the dose-response curves constructed from adenoviral MOIs by way of a standard nonlinear model based on Hill's equation.

\section{In vivo bioluminescence}

All animal experiments were approved by the Experimental Animal Committee of the Autonomous Government of Catalonia and performed in accordance with the recommendations for the proper care and use of laboratory animals.

PANC-1 cells $\left(2.5 \times 10^{6}\right)$ were injected subcutaneously into each posterior flank of BALB/c nude mice (Charles River France, Lyon, France). Ten days after tumor implantation, the tumors were divided into two groups $(n=10$ tumors per group): one group received a single intratumoral injection of AdGFPLuc at $2 \times 10^{8} \mathrm{PFU} /$ tumor and the second group received a single intratumoral injection of FGF2-AdGFPLuc at $2 \times 10^{8}$ PFU/tumor. On days 3 and 14 after adenoviral transduction, luciferase activity was visualized and quantified with an in vivo bioluminescence imaging system (IVIS; Xenogen/ Caliper Life Sciences, Alameda, CA). Images were captured and analyzed with Living Image 2.20.1 software (Xenogen/ Caliper Life Sciences) overlaid on Igor Pro 4.06A software (WaveMetrics, Lake Oswego, OR).

Briefly, the animals were anesthetized and the substrate firefly D-luciferin (Xenogen/Caliper Life Sciences) was administered intraperitoneally $(16 \mathrm{mg} / \mathrm{kg})$. Bioluminescent images were acquired $12 \mathrm{~min}$ after substrate administration, after an initial optimization study. For visualization purposes, a light image of the animal was also taken and merged with the bioluminescent image with the software overlay mode, permitting correlation of the areas of luciferase expression with mouse anatomy. Luciferase activity within the tumor was quantified by measuring the total amount of emitted light recorded by the charge-coupled device (CCD) camera. The results are expressed as photons per second per square centimeter and per steradian.

\section{Tumoral growth curves and survival studies}

PANC- 1 cells $\left(2.5 \times 10^{6}\right)$ or NP-31 cells $\left(5 \times 10^{6}\right)$ were injected subcutaneously into BALB/c nude mice (Charles River France). The tumors were allowed to grow, and treatment was 
initiated when the tumors reached a mean volume of $70 \mathrm{~mm}^{3}$. The tumors were randomized into five groups: group 1 received saline solution intratumorally and CPA intraperitoneally; group 2 received Ad- $C Y P 2 B 1$; group 3 received FGF2-Ad- $C Y P 2 B 1$; group 4 was treated with $\mathrm{Ad}-C Y P 2 B 1$ plus $\mathrm{CPA}$; and group 5 was treated with FGF2-Ad- $C Y P 2 B 1$ plus CPA. Considering the different kinetics in tumor growth between PANC-1 and NP31 xenografts, two treatment protocols were applied. In all cases, three intratumoral injections of $2 \times 10^{8}$ PFU of the respective recombinant adenovirus (Ad-CYP2B1 or FGF2-Ad$C Y P 2 B 1)$ were administered on days 11,13 , and 17 after tumor implantation (PANC-1 xenografts) or on days 9, 14, and 19 after tumor implantation (NP-31 xenografts). Moreover, groups 1,4 , and 5 received four intraperitoneal injections of CPA $(100 \mathrm{mg} / \mathrm{kg})$ on days $12,14,21$, and 27 after tumor implantation (PANC-1 xenografts) or on days 10, 15, 20, and 29 after tumor implantation (NP-31 xenografts). Detailed administration protocols are shown in Fig. 5 (see below). Tumor volume was measured every other day and was calculated according to the following formula: $V\left(\mathrm{~mm}^{3}\right)=$ [larger diameter $(\mathrm{mm}) \times$ smaller diameter $\left.^{2}\left(\mathrm{~mm}^{2}\right)\right] / 2$. Survival comparisons were displayed by means of Kaplan-Meier curves, and treated groups were compared by log-rank test.

\section{Statistical analysis}

Descriptive statistical analysis was performed with SYSTAT (SPSS, Chicago, IL). Results are expressed as means \pm SEM.

The Mann-Whitney nonparametric test was used for statistical analysis (two-tailed) of the in vitro and in vivo transduction efficiency studies. $p<0.05$ was taken as the level of significance.

$\mathrm{ID}_{50}$ values were estimated from the dose-response curves, using a nonlinear model. Confidence intervals were computed by bootstrap techniques (Venables, 2002). Comparison between FGF2-Ad- $C Y P 2 B 1$ and Ad- $C Y P 2 B 1$ was performed with a permutation test (Good, 1994). $p<0.05$ was considered statistically significant.

The in vivo tumor growth and survival analyses were performed with S-PLUS functions. In tumor growth analyses, mice, repeated measures, and tumor location in the mouse are considered nested classification factors. We associate randomeffect terms with the animal factor, the day of measurement, and the site nested in the animal. Hence, general linear-mixed models (Heitjan et al., 1993) are used to estimate the effects of treatment on tumor growth by taking nested and repeated design into account (Pinheiro and Bates, 2000). These models allowed us to make an analysis of the overall effect, and of the effect of each treatment. Estimation of coefficients, and their associated $p$ values, was based on restricted maximum likelihood. A plot of residual versus fitted values was used to check the assumptions of the model. Variance function structure was used to model the heterocedasticity of the day-to-day errors. $p<0.05$ (Bonferroni correction) was considered statistically significant after performing multiple comparisons among treated groups. Survival analyses were performed to analyze time-to-event probability. We define an event as the time at which an animal's tumor reached a preset threshold volume. We set two different scenarios: $200 \mathrm{~mm}^{3}$ (PANC-1 tumors) and $400 \mathrm{~mm}^{3}$ (NP-31 tumors). The survival curves obtained with the different treatments were compared, and animals whose tumor size never reached the threshold were included as rightcensored information. The log-rank test was used to determine the statistical significance of differences in time-to-event (Therneau and Grambsch, 2000). $p<0.05$ was considered statistically significant.

\section{RESULTS}

\section{Heterogeneous subcellular localization of FGFR-1 in pancreatic cancer cells}

To explore the feasibility of retargeting adenovirus to FGFRs in pancreatic tumors we first determined the expression and cellular localization of FGFR-1 in a panel of six pancreatic cancer cell lines by confocal immunofluorescence microscopy (Fig. 1A). We produced a series of six optical sections to more precisely assess the subcellular localization of FGFR-1. Immunostaining revealed a heterogeneous pattern of FGFR-1 distribution among the different cell lines. PANC-1, NP-31, and RWP-1 displayed moderate cytoplasmic and nuclear staining, but a strong membranous signal. BxPC-3 and NP-9 exhibited a mild signal in all compartments. Interestingly, high-level staining was observed in the nucleolus of BxPC-3. On the other hand, NP-18 cells showed weak cytoplasmic and membranous staining but strong perinuclear immunoreactivity.

We also confirmed the expression of FGFR-1 in a series of 30 pancreatic ductal adenocarcinomas. Twenty-nine of 30 tumor samples $(97 \%)$ showed positive immunostaining against FGFR-1 in neoplastic ducts, with intense signal detected in 16 of them (Fig. 1B, panel a). Detailed analysis of FGFR-1 expression showed a heterogeneous distribution inter- and intratumorally, with positive signal in the membrane that ranged from strong to weak and abundant immunoreactivity in the cytoplasm of neoplastic cells (Fig. 1B, panel b).

\section{Targeting adenovirus to FGF receptors results in enhanced and persistent transgene expression in pancreatic tumors}

We next studied the effects of FGF2-retargeted adenoviruses on transduction efficiency and transgene expression in pancreatic cancer cells. PANC-1, BxPC-3, NP-31, NP-9, RWP-1, and NP-18 cells were transduced with $100 \mathrm{MOI}$ of AdGFPLuc or FGF2-AdGFPLuc and, 3 days later, GFP-positive cells were visualized under a fluorescence microscope and luciferase activity was measured. A remarkable increase in GFP-positive cells was detected in PANC-1, BxPC-3, NP-31, and NP-9 cells transduced with the retargeted adenovirus, whereas no difference between the two viruses was observed in RWP-1 cells, and a reduced number of GFP-positive cells was found in NP-18 cells transduced with FGF2-AdGFPLuc (Fig. 2A). Next, we quantified transgene expression by measuring luciferase activity in the transduced cells. In PANC-1, BxPC-3, NP-31, and NP-9 cells the levels of luciferase activity achieved with the FGF2-AdGFPLuc adenovirus ranged from 10- to 100-fold higher than those achieved with the unmodified vector. However, similar levels were detected in RWP-1 cells with both viruses and a 6.6-fold decrease in luciferase activity was detected in NP-18 cells transduced with the redirected virus (Fig. 2B). In PANC-1, BxPC-3, 


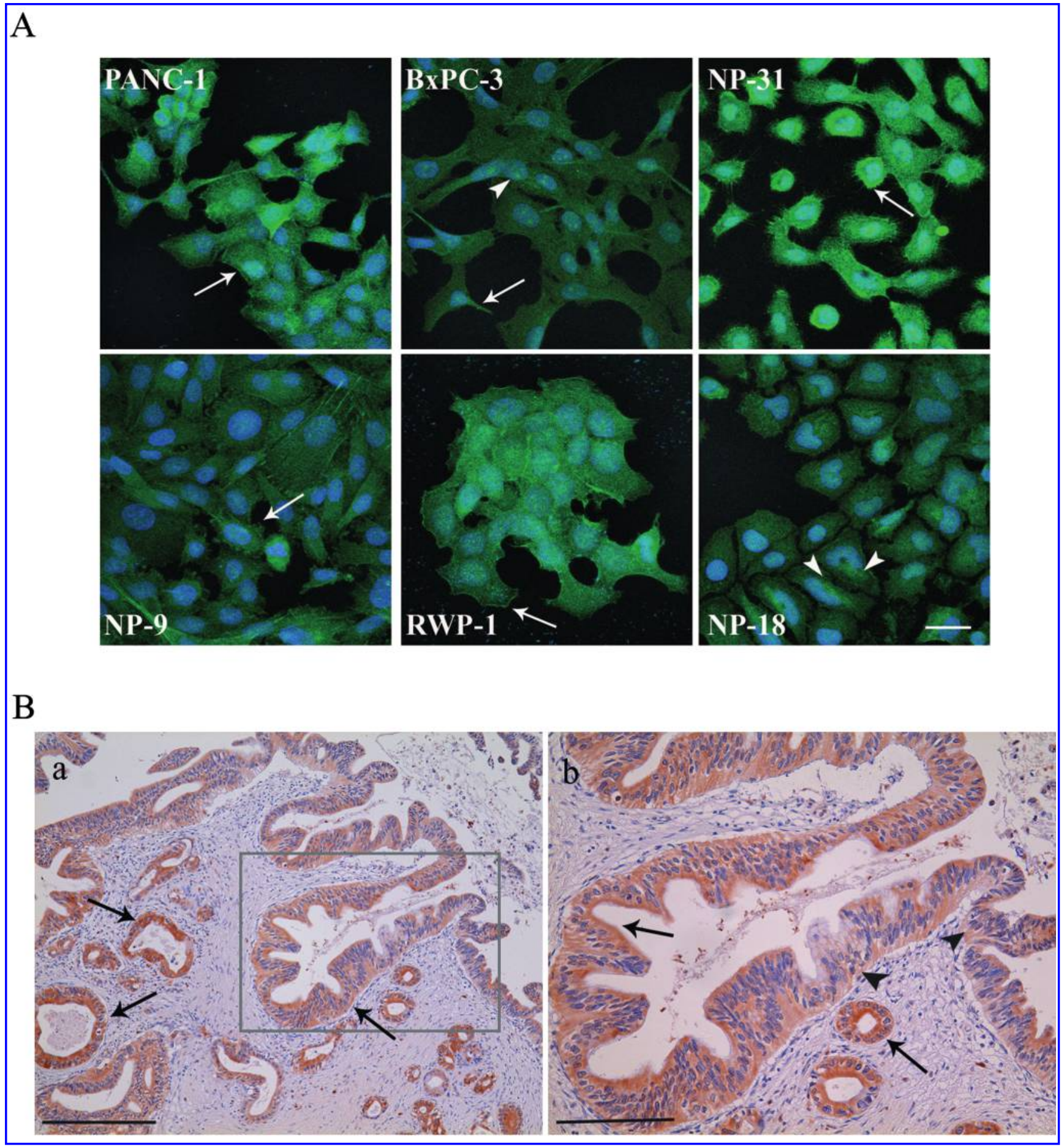

FIG. 1. FGFR-1 expression in pancreatic cancer cells and in human pancreatic cancer. (A) Confocal immunofluorescence microscopy analysis of pancreatic cancer cell lines PANC-1, BxPC-3, NP-31, NP-9, RWP-1, and NP-18, using a rabbit anti-FGFR-1 polyclonal antibody. Cells exhibited intense membranous and cytoplasmic FGFR-1 signal (arrows). Intense perinuclear staining was observed in NP-18 cells and in the nucleolus of BxPC-3 cells (arrowheads). Nuclei were stained with TO-PRO-3 iodide (blue). Scale bar: $20 \mu \mathrm{m}$. The images are representative of samples from at least three independent experiments. (B) Immunohistochemistry analysis of FGFR-1 expression in human pancreatic cancer tissues revealed membrane and cytoplasmic staining located in the neoplastic ducts (arrows) (panel a). At higher magnifications, areas of strong (arrows) to weak (arrowheads) membrane-positive staining were observed (panel b). Scale bars: panel a, $200 \mu \mathrm{m}$; panel b, $100 \mu \mathrm{m}$. 

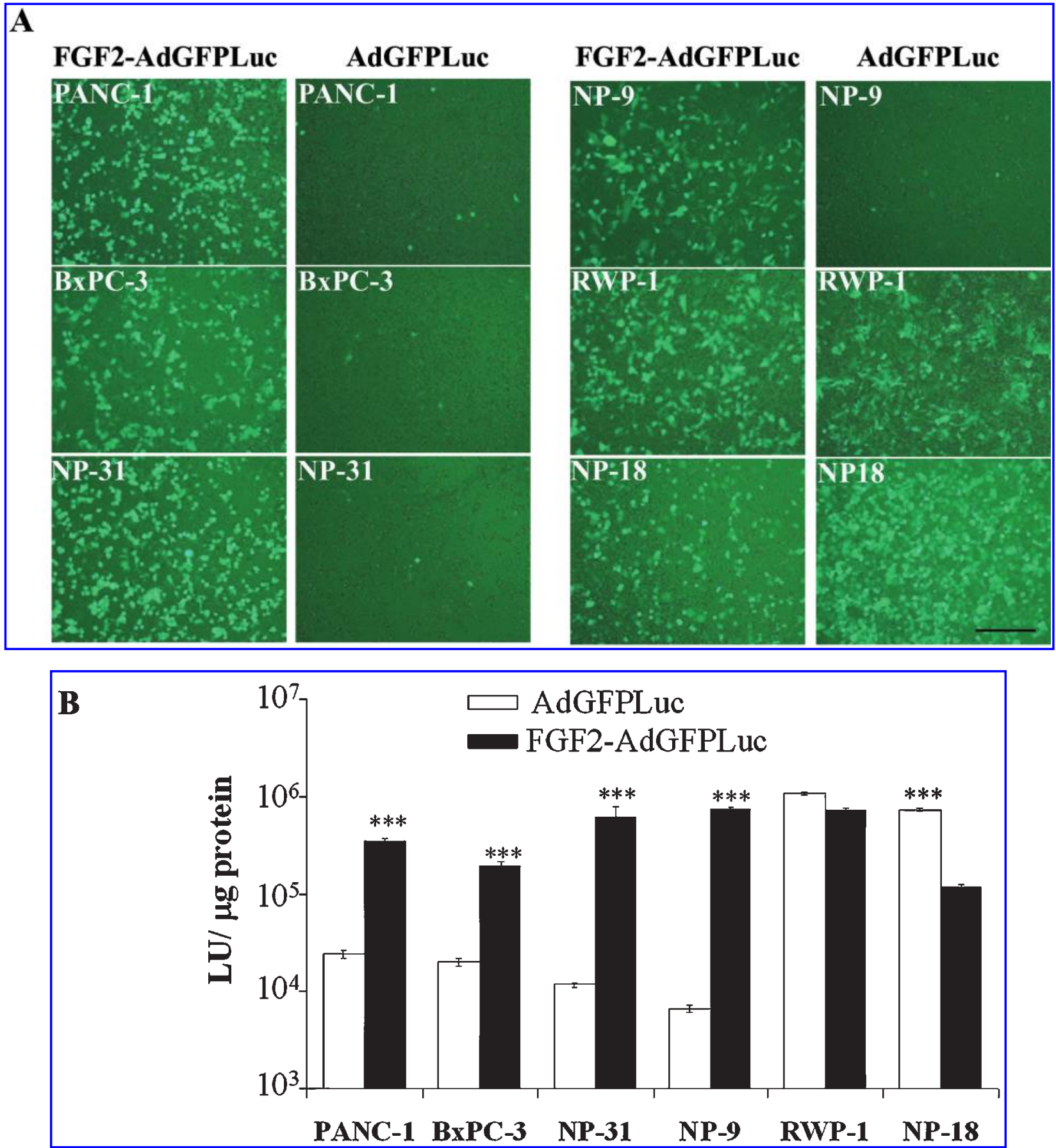

FIG. 2. Evaluation of FGF2-AdGFPLuc and AdGFPLuc transduction efficiency in vitro, in pancreatic cancer cells. Cells (20,000) were plated in triplicate in 96-well plates. GFP and firefly luciferase expression were determined from the same cell cultures 72 hr after AdGFPLuc or FGF2-AdGFPLuc transduction (MOI of 100). (A) GFP was visualized in live cells by phase-contrast fluorescence microscopy. Scale bar: $200 \mu \mathrm{m}$. (B) Luciferase expression was quantified and normalized to total protein levels. Results are expressed as light units per microgram protein. Values are represented as means \pm SEM of three independent experiments. $* * * p<0.0001$.

NP-31, RWP-1, and NP-18 cells lines a correlation between luciferase activity and GFP was observed. However, in NP-9 cells high levels of luciferase expression were detected with the FGF2-retargeted virus although only a moderate increase in GFP-positive cells was observed.
We next investigated the efficiency of retargeting adenovirus to FGFRs in PANC-1 tumor-bearing mice. First, we confirmed that PANC-1 cells, when grown as xenografts, would still maintain the expression of FGFR-1. Positive FGFR-1 immunostaining was detected in ductlike cancer 
A
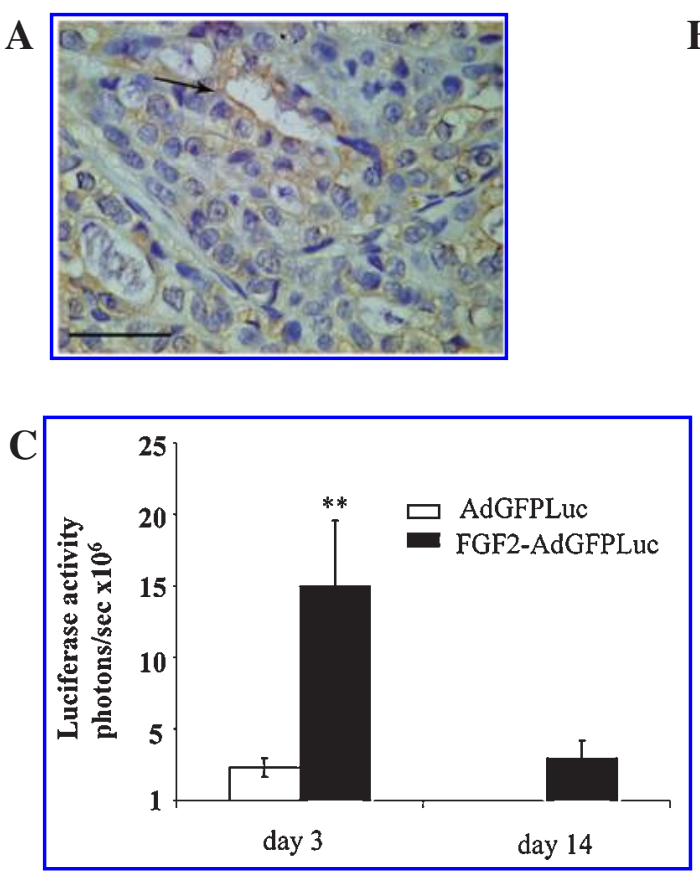

B

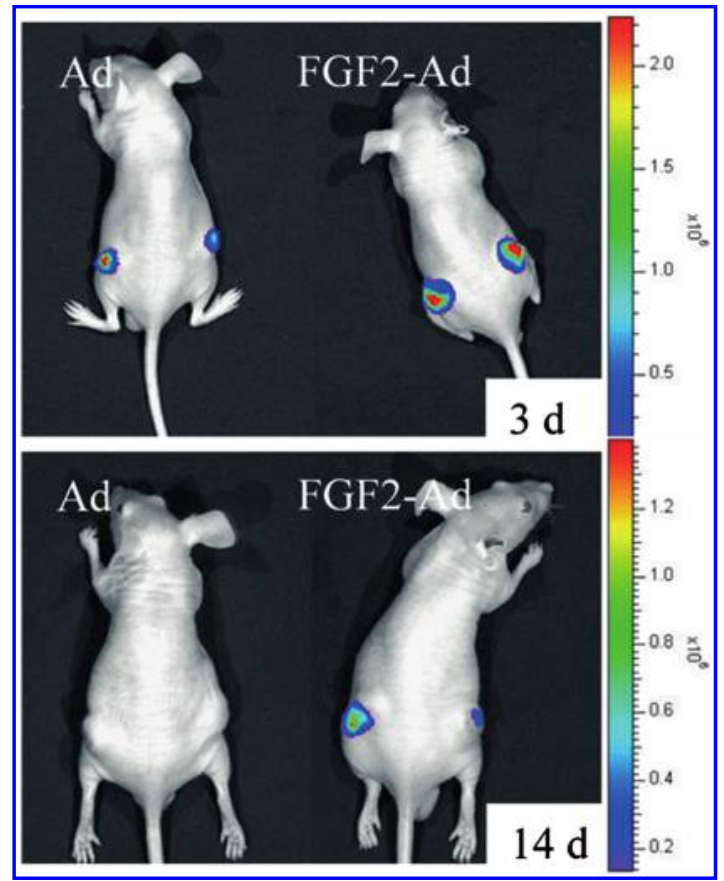

FIG. 3. In vivo bioluminescence studies. Comparative analysis of FGF2-AdGFPLuc and AdGFPLuc luciferase expression in vivo. (A) FGFR-1 immunohistochemical analysis in PANC-1 xenografts. An FGFR-1-positive signal was detected in the membrane and cytoplasm of ductlike cancer cells (arrow). Scale bar: $30 \mu \mathrm{m}$. (B and C) Randomized tumors were injected intratumorally with a single dose of $2 \times 10^{8}$ PFU of AdGFPLuc $(n=10)$ or FGF2-AdGFPLuc $(n=10)$. (B) Representative bioluminescence emission images of mice receiving AdGFPLuc (left) or FGF2-AdGFPLuc (right); images taken on day 3 (top) and day 14 (bottom). To minimize possible differences between groups, luminescent images were acquired with the same binning options and integration times. Luciferase activity is color coded with red, indicating the highest amount of emitted light ( 2 million photons/sec), and blue, indicating the lowest $(500,000$ photons/sec). (C) Quantification of luciferase expression in vivo on days 3 and 14. Luciferase activity recorded from the tumors was quantified by measuring the total amount of emitted light captured by the camera. Results are expressed as photons per second per square centimeter and per steradian. Significant differences were observed between the groups: $* * p<0.005$.

cells (Fig. 3A). To compare the in vivo transduction efficiency of FGF2-retargeted adenovirus with that of nonretargeted adenovirus, PANC-1 xenografts received a single dose of $2 \times 10^{8}$ PFU of FGF2-AdGFPLuc or AdGFPLuc and, 3 and 14 days later, luciferase activity was monitored by bioluminescence imaging. No bioluminescence was detected above background levels in mock-infected mice before D-luciferin administration. Bioluminescence images of representative animals transduced with FGF2-AdGFPLuc or AdGFPLuc are each displayed as a pseudocolor image overlaid on a gray-scale image of the whole mouse (Fig. 3B). Serial images were obtained from all animals and the mean photon flux relative to peak signal was determined (Fig. 3C). An intense signal was observed in all tumors on day 3 after adenoviral transduction. Importantly, a statistically significant increase in luciferase expression (6.2-fold, $p=0.005)$ was detected in tumors that received the FGF2-redirected virus. Moreover, on day 14 after viral administration luciferase activity was still detected in tumors that received the FGF2AdGFPLuc virus, whereas no light was detected from tumors injected with the nonredirected virus. These results clearly show increased expression of the transgene after in vivo FGF2-adenovirus retargeting.
Targeting Ad-CYP2B1 to FGFRs increases $C Y P 2 B 1 / C P A$ cytotoxicity in vitro

To study the consequences of redirecting the CYP2B1/CPA system to FGFRs in pancreatic tumors, six different pancreatic cancer cell lines, expressing variable membrane levels of FGFR-1, were mock-infected or transduced either with Ad$C Y P 2 B 1$ or FGF2-Ad-CYP2B1 at various viral doses. Four hours after transduction, the cells were treated with cyclophosphamide (CPA) for 4 days and cell viability was then assessed by MTT assay. Dose-response curves were obtained (Fig. 4A) and MOIs corresponding to the $\mathrm{ID}_{50}$ values were determined (Fig. 4B). Statistically significant differences in cytotoxicity between FGF2-Ad-CYP2B1 and Ad-CYP2B1 were observed in the various cell lines studied $(p<0.0001)$. An enhanced cytotoxic effect was obtained with the FGF2Ad- $C Y P 2 B 1 / C P A$ system in PANC-1 (4.6-fold), BxPC-3 (5.0fold), NP-9 (9.4-fold), and NP-31 (11.6-fold) cells. No differences were observed in RWP-1 cells, whereas a 3-fold reduction in cytotoxicity was detected in NP-18 cells treated with the redirected system. These results indicate that CYP2B1/CPA sensitivity can be highly increased by favoring vector transduction efficiency. 
A

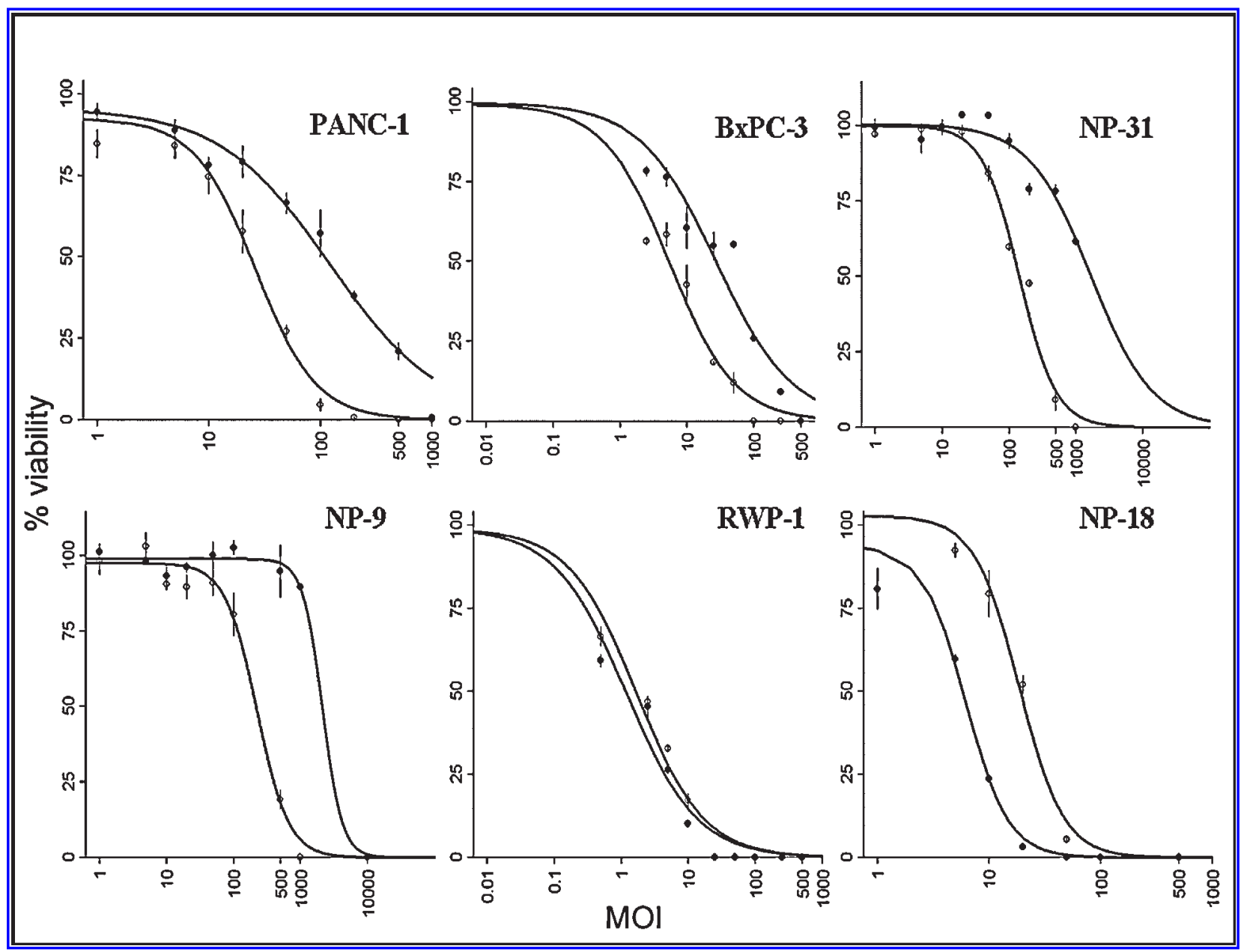

B

\begin{tabular}{||c|c|c|c|}
\hline & $\begin{array}{c}\text { FGF2-Ad- } \\
\text { CYP2B1/CPA } \\
\text { ID }_{50} \text { (95\% CI) }\end{array}$ & $\begin{array}{c}\text { Ad-CYP2B1/CPA } \\
\text { ID }_{50}(95 \% \text { CI) }\end{array}$ & $p$-value \\
\hline PANC-1 & $26.2(23.1,32)$ & $121.8(96.9,167.4)$ & $<0.0001$ \\
\hline BXPC-3 & $5.5(1.0,1.6)$ & $27.4(21.0,45.0)$ & $<0.001$ \\
\hline NP-31 & $143.3(131.8,162.2)$ & $1668.8(1128.4,2571.1)$ & $<0.0001$ \\
\hline NP-9 & $224(186.2,280.1)$ & $2114(1227.3,2520.1)$ & $<0.0001$ \\
\hline RWP-1 & $1.69(1.44,2.2)$ & $1.18(1.0,1,6)$ & $>0.05$ \\
\hline NP-18 & $18.6(16.2,22.3)$ & $6.2(5.3,7.1)$ & $<0.0001$ \\
\hline
\end{tabular}

FIG. 4. Dose-response curves of pancreatic cancer cells transduced with Ad-CYP2B1 or FGF2-Ad-CYP2B1 and treated with CPA. Cells $\left(5 \times 10^{3}\right.$ per well) were seeded in triplicate and infected with a dose range of 0 to 10,000 MOI of Ad-CYP2B1 or FGF2Ad-CYP2B1. Four hours later $0.5 \mathrm{~m} M$ CPA was added to the culture. Cell viability was measured after 4 days of treatment. Mockinfected cultures receiving $0.5 \mathrm{~m} M$ CPA were considered $100 \%$ viable. (A) PANC-1, BxPC-3, NP-31, NP-9, RWP-1, and NP-18 dose-response curves. Curve values are plotted as means \pm SEM of three independent experiments. Open circles, FGF2-AdCYP2B1/CPA; solid circles, Ad-CYP2B1/CPA. (B) ID 50 values, 95\% confidence interval (95\% CI), and $p$ values were obtained from at least three independent experiments. 
Targeting Ad-CYP2B1/CPA to FGF receptors leads to increased antitumoral effect in PANC-1 and NP-31 xenografts

We next examined the ability of Ad-CYP2B1 or FGF2-Ad$C Y P 2 B 1$, in combination with CPA, to inhibit tumor growth in vivo. PANC-1 and NP-31 xenografts were established in nude mice. Tumorigenic potential is governed by complex processes and has many requirements (Hanahan and Weinberg, 2000). The expansion of solid tumors has particular characteristics for any given tumor model. As can be observed in Fig. 5, the tumor growth kinetics of PANC-1 and NP-31 are quite different: PANC-1 tumors grow much more rapidly than NP-31 tumors. Bearing this in mind, we decided to apply a slightly different treatment schedule for each tumor model.

PANC-1 tumors received Ad-CYP2B1 or FGF2-Ad-CYP2B1 at a viral dose of $6 \times 10^{8} \mathrm{PFU} /$ tumor, distributed in two intratumoral injections spaced by 1 day, and a third injection 4 days later. When stated, the mice received CPA at $100 \mathrm{mg} / \mathrm{kg} 24 \mathrm{hr}$ after the first two viral injections. Four days after the last viral injection, mice received a third dose of CPA that was repeated 6 days later. As shown in Fig. 5A, the three control groups (mice treated with CPA and mice injected with Ad-CYP2B1 or FGF2-Ad-CYP2B1 and not receiving CPA) showed continuous and stable growth. However, CPA treatment slightly inhibited PANC-1 tumor growth, consistent with liver $P-450$ CPA metabolization. Regarding the two virus/CPA-treated groups, the mice receiving FGF2-Ad- $C Y P 2 B 1$ plus CPA showed the most dramatic response $(p<0.0001)$. Sustained regression in tumor volume began on day 12, after the first CPA injection, leading to an increase in median survival time, as observed in the Kaplan-Meier curve. Tumors injected with Ad-CYP2B1 and treated with CPA showed an inhibition of tumor growth that was statistically significant when compared with the control group, which received virus but not CPA $(p=0.0005)$. Both treatments, FGF2-Ad-CYP2B1 plus CPA and Ad-CYP2B1 plus $\mathrm{CPA}$, induced a reduction in tumor progression that was statistically significant when compared with the CPA group ( $p=$ 0.0071 and $p=0.0459$, respectively). Importantly, it was on day 19 , once the total viral dose had been administered, when statistically significant differences in tumor growth between the two treated groups were first observed $(p<0.05)$. Moreover, a statistically significant difference in median survival rate between the two treated groups was also observed (log-rank test: 0.0444) (Fig. 5A).

NP-31 tumors received Ad-CYP2B1 or FGF2-Ad-CYP2B1 at a viral dose of $6 \times 10^{8} \mathrm{PFU} /$ tumor, distributed in three intratumoral injections spaced by 5 days each. When stated, the mice received CPA at $100 \mathrm{mg} / \mathrm{kg} 24 \mathrm{hr}$ after each viral injection. Ten days after the last viral injection, the mice received an additional dose of CPA. As shown in Fig. 5B, the three control groups (CPA, Ad-CYP2B1, and FGF2-Ad-CYP2B1) showed continuous and stable growth. Again, as in PANC-1 xenografts, the mice receiving FGF2-Ad-CYP2B1 plus CPA exhibited the most dramatic response $(p=0.0073)$. Maximum regression in tumor volume was observed on day 21 , after the administration of all three viral doses. As shown in the Kaplan-Meier curves, a 2-fold increase in the median survival time was observed in animals treated with FGF2-Ad-CYP2B1 plus CPA, as compared with the three control groups. Mice treated with Ad-CYP2B1 plus CPA showed a slow progression in tumor growth that was significantly different on days 21 and 24 and at the end of the experiment, when compared with the group that received the virus but not CPA. Importantly, on day 15 , after the first virus/CPA treatment, statistically significant differences in tumor growth between the two treated groups were observed $(p<0.05)$. Moreover, a statistically significant difference in median survival rate between the two treated groups was also found (log-rank test: 0.01) (Fig. 5B).

In an attempt to gain insight concerning the enhanced antitumoral effect achieved with the FGF2-retargeted adenovirus, we decided to investigate CYP2B1 expression in tumors injected with redirected or nonredirected virus. PANC-1 and NP-31 tumors were injected with Ad-CYP2B1 or FGF2-Ad$C Y P 2 B 1$ at $2 \times 10^{8} \mathrm{PFU} /$ tumor, and 3 days later tumors were excised and analyzed for CYP2B1 expression by immunohistochemistry. PANC-1 and NP-31 xenografts injected with either virus showed positive staining for CYP2B1. Interestingly, tumors injected with FGF2-Ad-CYP2B1 expressed CYP2B1 protein in a greater number of cells, suggesting that the FGF2directed virus was reaching a larger area of the tumor mass (Fig. 6A and B). Moreover, with the FGF2-directed virus, increased CYP2B1 signal was detected in the cytoplasm, indicating most probably that a higher number of viral particles had entered per cell (Fig. 6A, inset).

\section{DISCUSSION}

The bioactivation of cyclophosphamide or ifosfamide by $P$ 450 enzymes has been shown to trigger antitumoral responses, both in preclinical and clinical studies, proving the therapeutic potential of this approach for pancreatic cancer therapy (Lohr et al., 2001).

Many different approaches have been addressed to optimize $P-450$ efficacy, from increasing the catalytic activity of the $P$ 450 transgene with the $P-450$ reductase gene (Chen et al., 1997) to attempting to overcome the inability of current gene therapy vectors to achieve gene transduction over a significant tumor area. Along these lines, it is important to note that, in herpesvirus type 1-infected tumors, cyclophosphamide itself has been reported to act as a facilitator of viral survival and propagation within the tumors (Ikeda et al., 1999, 2000). In addition, strategies based on amplifying the bystander cytotoxic effect of $P$-450-expressing tumor cells (Schwartz et al., 2002), as well as strategies based on using conditionally replicative viruses (Jounaidi and Waxman, 2004; Tyminski et al., 2005), have been tested.

The present study shows that it is possible to enhance CYP2B1/CPA antitumoral activity in pancreatic tumor models by retargeting adenoviral vectors expressing the $C Y P 2 B 1$ gene to FGF receptors. This approach is based on the use of a conjugate protein composed of the FGF2 ligand linked to the Fab' fragment of the anti-adenoviral knob antibody. This targeting system has previously been shown to enhance adenoviral transduction of cells that express high-affinity FGF receptors (Goldman et al., 1997; Rancourt et al., 1998; Wang et al., 2005). Several studies have also shown that pancreatic tumor cells and pancreatic adenocarcinoma overexpress FGFRs (Kobrin et al., 1993; Leung et al., 1994; Kleeff et al., 2002; Tyminski et al., 


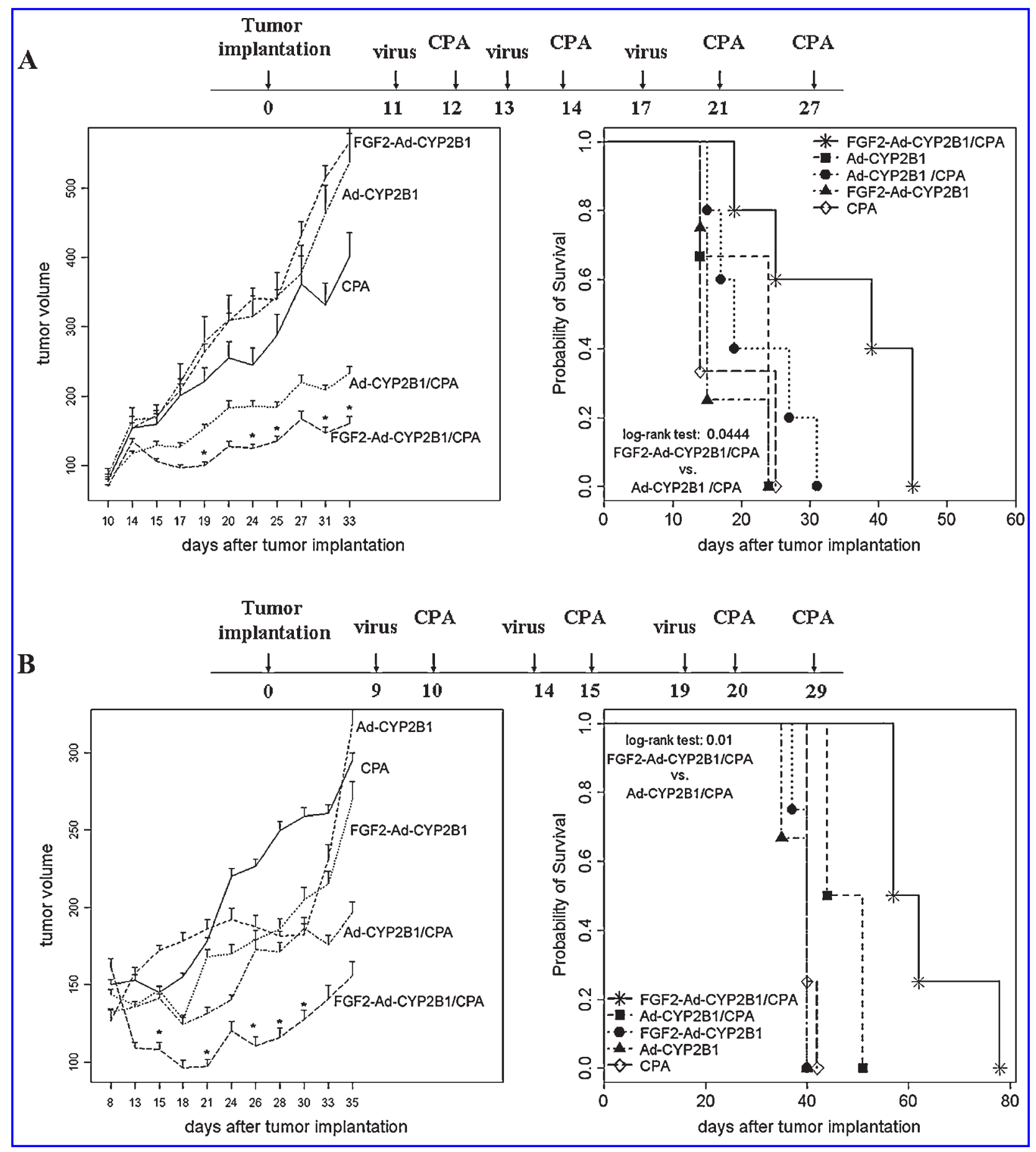

FIG. 5. Tumoral growth and Kaplan-Meier survival curves of two pancreatic cancer xenograft models treated with Ad-CYP2B1 or FGF2-Ad-CYP2B1 plus CPA. (A) Animals bearing PANC-1 xenografts were randomized to five groups: three control groups: CPA ( $n=6$ tumors), Ad- $C Y P 2 B 1$ ( $n=6$ tumors), and FGF2-Ad-CYP2B1 ( $n=8$ tumors) and two treated groups: Ad- $C Y P 2 B 1$ plus CPA ( $n=9$ tumors) and FGF2-Ad-CYP2B1 plus CPA $(n=9$ tumors). Three intratumoral injections of Ad-CYP2B1 or FGF2-Ad-CYP2B1 $\left(2 \times 10^{8} \mathrm{PFU} /\right.$ dose $)$ and four intraperitoneal injections of CPA $(100 \mathrm{mg} / \mathrm{kg}$ per dose $)$ were administered according to the protocol indicated. (B) Mice bearing NP-31 tumors were randomized into three control groups: CPA ( $n=8$ tumors), Ad- $C Y P 2 B 1$ ( $n=6$ tumors), and FGF2-Ad-CYP2B1 ( $n=8$ tumors) and two treated groups: Ad-CYP2B1 plus CPA $(n=$ 8 tumors) and FGF2-Ad- $C Y P 2 B 1$ plus CPA ( $n=8$ tumors). Three intratumoral injections of Ad-CYP2B1 or FGF2-Ad- $C Y P 2 B 1$ $\left(2 \times 10^{8} \mathrm{PFU} /\right.$ dose $)$ and four intraperitoneal injections of CPA $(100 \mathrm{mg} / \mathrm{kg}$ per dose $)$ were administered according to the protocol indicated. Tumor growth curves (left) and Kaplan-Meier survival curves (right) are plotted. Comparisons of overall growth curves are described in Results. Significance, ${ }^{*} p<0.05$, refers to a comparison of the two treated groups (Ad-CYP2B1 plus CPA and FGF2-Ad-CYP2B1 plus CPA) at each time point studied. Survival curves were compared by log-rank test. A significant increase in survival was achieved in animals treated with FGF2-Ad-CYP2B1 plus CPA versus animals treated with Ad-CYP2B1 plus CPA (log-rank test $=0.04$, PANC- 1 ; log-rank test $=0.01, \mathrm{NP}-31)$. 


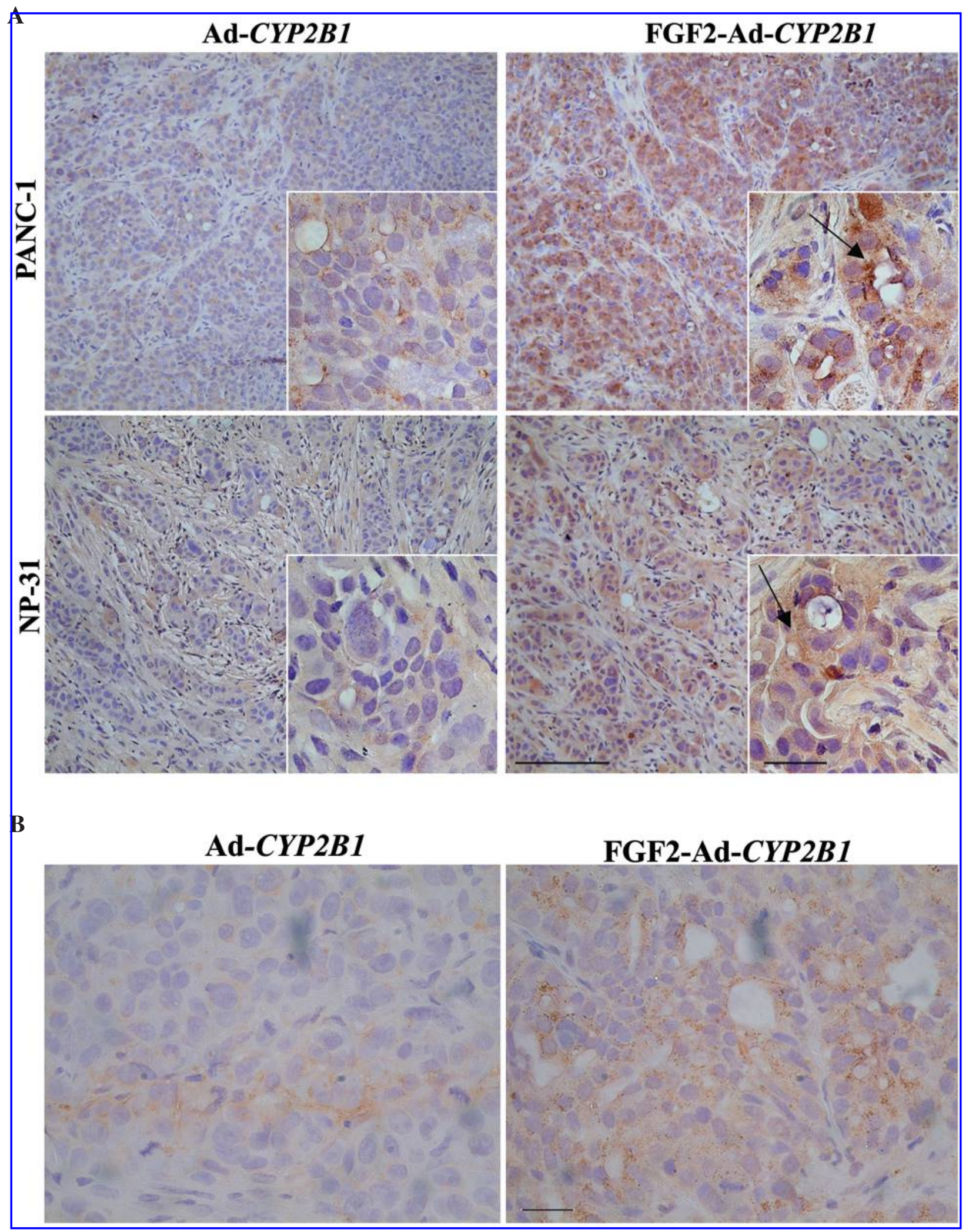

FIG. 6. CYP2B1 expression in pancreatic cancer tumors injected with Ad-CYP2B1 or FGF2-Ad-CYP2B1. Tumors were injected with a single dose $\left(2 \times 10^{8}\right.$ PFU/tumor) of Ad-CYP2B1 (left) or FGF2-Ad-CYP2B1 (right). Three days later the tumors were excised and CYP2B1 expression was analyzed by immunohistochemistry. (A) PANC-1 (top) and NP-31 (bottom): Stronger positive staining was detected in tumors injected with FGF2-Ad-CYP2B1. Scale bars: $50 \mu \mathrm{m}$. Higher magnifications (insets) reveal CYP2B1 expression in the cytoplasm of tumoral cells (arrows). Scale bar: $10 \mu \mathrm{m}$. (B) PANC-1: An increased number of positive cells was detected in tumors injected with FGF2-Ad-CYP2B1. Scale bar: $20 \mu \mathrm{m}$. 
2005). However, what is demonstrated here is that for the retargeting approach to work efficiently it is important not only to know that there is FGFR expression but also, and more relevantly, to precisely define FGFR localization in the tumor. Our data show that FGFR-1 is overexpressed and highly heterogeneously distributed in pancreatic tumor cells, with a membrane localization that ranges from a strong to a weak signal, depending on the cell line. This uneven localization pattern of FGFR-1 in the ductal cancer cells was also present in tumor samples. The variable expression of FGF receptors in the plasma membrane of tumor cell lines was not restricted to FGFR-1; it also extended to the other family receptors (FGFR1-4; data not shown).

One could argue that endogenous FGF2 production could compete with FGF2-adenoviruses for binding to FGFRs, thereby limiting their transduction capability. However, this would not be an issue because endogenous FGF2 would not be biologically available to bind to FGFRs (Ornitz and Itoh, 2001).

We observed that PANC-1, NP-31, and RWP-1 cells, all having a strong FGFR-1 membrane signal, showed a high number of GFP-positive cells after FGF2-AdGFPLuc transduction, whereas NP-9 and BxPC-3 cells, with moderate membrane signal, and NP-18 cells, with a weak membrane signal, showed fewer GFP-positive cells. Thus, these results indicate an association between membrane FGFR localization and GFP expression when FGF2-adenovirus is used.

Interestingly, infection with the retargeted adenovirus resulted in increased GFP expression and enhanced luciferase activity in four of the six cell lines studied, as compared with the nonretargeted virus, whereas no differences were observed in RWP-1 cells, and a lower level of expression was observed in NP-18 cells. The fact that NP-18 cells presented higher transduction efficiency with the nonredirected virus would be in agreement with the elevated CAR levels (our unpublished data) and the weak FGFR membrane signal observed. However, we identified elevated luciferase expression in NP-9 cells, but a moderate increase in GFP-positive cells. These results are in line with previous observations that had reported enhanced transgene expression, independent of viral entry, suggesting the involvement of other cell mechanisms in FGF2 retargeting (Doukas et al., 1999; Hoganson et al., 2001).

Targeting the CYP2B1/CPA system to FGFRs resulted in a relevant cytotoxic effect in PANC-1, BxPC-3, NP-9, and NP31 cells that was 4.6-, 5.0-, 9.4-, and 11.6-fold stronger (respectively) than that achieved with the nonredirected system, whereas similar effects were observed in RWP-1 cells and a reduced response was obtained in NP-18 cells. These results correlate with the transduction efficiency data, thus indicating that the differences in CYP2B1/CPA cytotoxicity could be the consequence of both an increase in viral entry and the enhancement of transgene expression. Interestingly, these findings showed that cells that were apparently resistant to CYP2B1/CPA treatment might be sensitized if infected with FGF2-Ad-CYP2B1, targeting the FGF receptors, and treated with CPA. Similar observations were made by Kleeff et al., who redirected the TK/GCV system to FGFRs, although the effect was not that strong and was observed in only two of the six cell lines studied (Kleeff et al., 2002). A common cell line, PANC-1, was used in both studies and the application of the two treatments, FGF2-AdTK/GCV and FGF2-Ad-
CYP2B1/CPA, had completely different outcomes. Whereas resistance to GCV was reported by Kleeff et al., we observed a clear increase in CPA sensitivity. The apparent discrepancy may be explained by the ability of this particular cell line to respond to TK/GCV or CYP2B1/CPA cytotoxic therapies.

Interestingly, in vivo PANC-1 tumors, as was found with NP31 tumors, showed a greater response when treated with the redirected virus FGF2-Ad-CYP2B1 and CPA. A statistically significant reduction in tumor volume and a significant increase in survival were clearly appreciated. Several factors may have contributed to the success of these treatments: for example, the optimization of the CYP2B1/CPA administration protocols, on the basis of PANC-1 or NP-31 tumor behavior, plus the use of a repeated CPA dosing schedule and retreatment, as opposed to a single bolus or continuous drug exposure (Browder et al., 2000; Schwartz et al., 2002; Jounaidi and Waxman, 2004; Tyminski et $a l ., 2005)$. Moreover, the increased persistence of the protein in the tumor, observed in the bioluminescence studies, may have also facilitated the response to CPA readministrations. Furthermore, the increased efficacy of redirected FGF2-AdCYP2B1/CPA could also be explained by the data we obtained from our analysis of CYP2B1 expression in tumors. An increase in the number of CYP2B1-expressing cells plus the enhanced expression per cell, would appear to suggest that the redirected virus was able to reach an extended tumor area and that probably a greater number of viral particles would have entered each cell. These results suggest that with this retargeting system the intratumoral injection limitations, which have been associated with adenovirus, because of viral particle retention at the site of injection (Vile et al., 2002), might be partially overcome.

In summary, the present report demonstrates for the first time an enhanced antitumoral response in vitro and in vivo by FGF2redirected adenovirus in pancreatic cancer models, and suggests that retargeting the suicide CYP2B1/CPA system to FGFRs could be of clinical use for a subgroup of pancreatic cancer patients, with tumors that precisely overexpress FGF receptors at high density in the cell membrane.

\section{ACKNOWLEDGMENTS}

This work was supported by grants from the Spanish Ministry of Education and Science, FEDER (SAF-2002-04122C03-02/03), and BIO2005-08682-C03-02 and received partial support through grants from the Instituto de Salud Carlos IIII (G03/156) and RTICCC (C03/10) and from the Generalitat de Catalunya. M. Huch is a predoctoral fellow (BEFI) from the Instituto de Salud Carlos III and D. Abate-Daga is a predoctoral fellow from the Fundación Carolina. The authors thank Gabriel Capellà for assistance with the pancreatic ductal adenocarcinoma patient samples.

\section{REFERENCES}

ABRAMS, R.A. (2003). Adjuvant therapy for pancreatic adenocarcinoma: What have we learned since 1985? Int. J. Radiat. Oncol. Biol. Phys. 56, 3-9.

AGHI, M., CHOU, T.C., SUlING, K., BREAKEFIELD, X.O., and CHIOCCA, E.A. (1999). Multimodal cancer treatment mediated by 
a replicating oncolytic virus that delivers the oxazaphosphorine/rat cytochrome P450 2B1 and ganciclovir/herpes simplex virus thymidine kinase gene therapies. Cancer Res. 59, 3861-3865.

ALEMANY, R., and CURIEL, D.T. (2001). CAR-binding ablation does not change biodistribution and toxicity of adenoviral vectors. Gene Ther. 8, 1347-1353.

ANDERS, M., CHRISTIAN, C., McMAHON, M., McCORMICK, F., and KORN, W.M. (2003). Inhibition of the Raf/MEK/ERK pathway up-regulates expression of the coxsackievirus and adenovirus receptor in cancer cells. Cancer Res. 63, 2088-2095.

BECKER, T.C., NOEL, R.J., COATS, W.S., GOMEZ-FOIX, A.M., ALAM, T., GERARD, R.D., and NEWGARD, C.B. (1994). Use of recombinant adenovirus for metabolic engineering of mammalian cells. Methods Cell Biol. 43, 161-189.

BROWDER, T., BUTTERFIELD, C.E., KRALING, B.M., SHI, B., MARSHALL, B., O'REILLY, M.S., and FOLKMAN, J. (2000). Antiangiogenic scheduling of chemotherapy improves efficacy against experimental drug-resistant cancer. Cancer Res. 60, 1878-1886.

CARRIO, M., VISA, J., CASCANTE, A., ESTIVILL, X., and FILLAT, C. (2002). Intratumoral activation of cyclophosphamide by retroviral transfer of the cytochrome $\mathrm{P} 4502 \mathrm{~B} 1$ in a pancreatic tumor model: Combination with the HSVtk/GCV system. J. Gene Med. 4, 141-149.

CHASE, M., CHUNG, R.Y., and CHIOCCA, E.A. (1998). An oncolytic viral mutant that delivers the CYP2B1 transgene and augments cyclophosphamide chemotherapy. Nat. Biotechnol. 16, 444-448.

CHEN, L., YU, L.J., and WAXMAN, D.J. (1997). Potentiation of cytochrome P450/cyclophosphamide-based cancer gene therapy by coexpression of the P450 reductase gene. Cancer Res. 57, 4830-4837.

DOUKAS, J., HOGANSON, D.K., ONG, M., YING, W., LACEY, D.L., BAIRD, A., PIERCE, G.F., and SOSNOWSKI, B.A. (1999). Retargeted delivery of adenoviral vectors through fibroblast growth factor receptors involves unique cellular pathways. FASEB J. 13, 1459-1466.

GOLDMAN, C.K., ROGERS, B.E., DOUGLAS, J.T., SOSNOWSKI, B.A., YING, W., SIEGAL, G.P., BAIRD, A., CAMPAIN, J.A., and CURIEL, D.T. (1997). Targeted gene delivery to Kaposi's sarcoma cells via the fibroblast growth factor receptor. Cancer Res. 57, 1447-1451.

GOOD, P.I. (1994). Permutation Tests for Testing Hypotheses. (Springer-Verlag, New York).

GU, D.L., GONZALEZ, A.M., PRINTZ, M.A., DOUKAS, J., YING, W., D'ANDREA, M., HOGANSON, D.K., CURIEL, D.T., DOUGLAS, J.T., SOSNOWSKI, B.A., BAIRD, A., AUKERMAN, S.L., and PIERCE, G.F. (1999). Fibroblast growth factor 2 retargeted adenovirus has redirected cellular tropism: Evidence for reduced toxicity and enhanced antitumor activity in mice. Cancer Res. 59, 2608-2614.

HANAHAN, D., and WEINBERG, R.A. (2000). The hallmarks of cancer. Cell 100, 57-70.

HEITJAN, D.F., MANNI, A., and SANTEN, R.J. (1993). Statistical analysis of in vivo tumor growth experiments. Cancer Res. 53, 6042-6050.

HOGANSON, D.K., SOSNOWSKI, B.A., PIERCE, G.F., and DOUKAS, J. (2001). Uptake of adenoviral vectors via fibroblast growth factor receptors involves intracellular pathways that differ from the targeting ligand. Mol. Ther. 3, 105-112.

ICHIKAWA, T., PETROS, W.P., LUDEMAN, S.M., FANGMEIER, J., HOCHBERG, F.H., COLVIN, O.M., and CHIOCCA, E.A. (2001). Intraneoplastic polymer-based delivery of cyclophosphamide for intratumoral bioconversion by a replicating oncolytic viral vector. Cancer Res. 61, 864-868.

IKEDA, K., ICHIKAWA, T., WAKIMOTO, H., SILVER, J.S., DEISBOECK, T.S., FINKELSTEIN, D., HARSH, G.R., IV, LOUIS, D.N., BARTUS, R.T., HOCHBERG, F.H., and CHIOCCA, E.A. (1999). Oncolytic virus therapy of multiple tumors in the brain requires sup- pression of innate and elicited antiviral responses. Nat. Med. 5, 881-887.

IKEDA, K., WAKIMOTO, H., ICHIKAWA, T., JHUNG, S., HOCHBERG, F.H., LOUIS, D.N., and CHIOCCA, E.A. (2000). Complement depletion facilitates the infection of multiple brain tumors by an intravascular, replication-conditional herpes simplex virus mutant. J. Virol. 74, 4765-4775.

JOUNAIDI, Y., and WAXMAN, D.J. (2004). Use of replication-conditional adenovirus as a helper system to enhance delivery of P450 prodrug-activation genes for cancer therapy. Cancer Res. 64, 292-303.

KARLE, P., RENNER, M., SALMONS, B., and GUNZBURG, W.H. (2001). Necrotic, rather than apoptotic, cell death caused by cytochrome P450-activated ifosfamide. Cancer Gene Ther. 8, 220-230.

KLEEFF, J., FUKAHI, K., LOPEZ, M.E., FRIESS, H., BUCHLER, M.W., SOSNOWSKI, B.A., and KORC, M. (2002). Targeting of suicide gene delivery in pancreatic cancer cells via FGF receptors. Cancer Gene Ther. 9, 522-532.

KOBRIN, M.S., YAMANAKA, Y., FRIESS, H., LOPEZ, M.E., and KORC, M. (1993). Aberrant expression of type I fibroblast growth factor receptor in human pancreatic adenocarcinomas. Cancer Res. 53, 4741-4744.

LEUNG, H.Y., GULLICK, W.J., and LEMOINE, N.R. (1994). Expression and functional activity of fibroblast growth factors and their receptors in human pancreatic cancer. Int. J. Cancer 59, 667-675.

LI, Y., PONG, R.C., BERGELSON, J.M., HALL, M.C., SAGALOWSKY, A.I., TSENG, C.P., WANG, Z., and HSIEH, J.T. (1999). Loss of adenoviral receptor expression in human bladder cancer cells: A potential impact on the efficacy of gene therapy. Cancer Res. 59, 325-330.

LOHR, M., MULLER, P., KARLE, P., STANGE, J., MITZNER, S., JESNOWSKI, R., NIZZE, H., NEBE, B., LIEBE, S., SALMONS, B., and GUNZBURG, W.H. (1998). Targeted chemotherapy by intratumour injection of encapsulated cells engineered to produce CYP2B1, an ifosfamide activating cytochrome P450. Gene Ther. 5, 1070-1078.

LOHR, M., HOFFMEYER, A., KROGER, J., FREUND, M., HAIN, J., HOLLE, A., KARLE, P., KNOFEL, W.T., LIEBE, S., MULLER, P., NIZZE, H., RENNER, M., SALLER, R.M., WAGNER, T., HAUENSTEIN, K., GUNZBURG, W.H., and SALMONS, B. (2001). Microencapsulated cell-mediated treatment of inoperable pancreatic carcinoma. Lancet 357, 1591-1592.

McDONALD, J.R., ONG, M., SHEN, C., PARANDOOSH, Z., SOSNOWSKI, B., BUSSELL, S., and HOUSTON, L.L. (1996). Largescale purification and characterization of recombinant fibroblast growth factor-saporin mitotoxin. Protein Expr. Purif. 8, 97-108.

MERCADE, E., CASCAllo, M., CARRIO, M., CALBO, J., GOMEZ-TREVINO, A., FILLAT, C., GOMEZ-FOIX, A.M., and MAZO, A. (2001). Treatment based on a combination of the CYP2B1/cyclophosphamide system and p53 delivery enhances tumour regression in human pancreatic cancer. Ann. Oncol. 12, 379-388.

MULLER, P., JESNOWSKI, R., KARLE, P., RENZ, R., SALLER, R., STEIN, H., PUSCHEL, K., vON ROMBS, K., NIZZE, H., LIEBE, S., WAGNER, T., GUNZBURG, W.H., SALMONS, B., and LOHR, M. (1999). Injection of encapsulated cells producing an ifosfamideactivating cytochrome P450 for targeted chemotherapy to pancreatic tumors. Ann. N.Y. Acad. Sci. 880, 337-351.

OHTA, T., YAMAMOTO, M., NUMATA, M., ISEKI, S., TSUKIOKA, Y., MIYASHITA, T., KAYAHARA, M., NAGAKAWA, T., MIYAZAKI, I., NISHIKAWA, K., and YOSHITAKE, Y. (1995). Expression of basic fibroblast growth factor and its receptor in human pancreatic carcinomas. Br. J. Cancer 72, 824-831.

ORNITZ, D.M., and ITOH, N. (2001). Fibroblast growth factors. Genome Biol. 2, REVIEWS3005. 
PINHEIRO, J.C., and BATES, D.M. (2000). Mixed-Effects Models in $S$ and $S$-PLUS. (Springer-Verlag, New York).

RANCOURT, C., ROGERS, B.E., SOSNOWSKI, B.A., WANG, M., PICHE, A., PIERCE, G.F., ALVAREZ, R.D., SIEGAL, G.P., DOUGLAS, J.T., and CURIEL, D.T. (1998). Basic fibroblast growth factor enhancement of adenovirus-mediated delivery of the herpes simplex virus thymidine kinase gene results in augmented therapeutic benefit in a murine model of ovarian cancer. Clin. Cancer Res. 4, 2455-2461.

SCHWARTZ, P.S., and WAXMAN, D.J. (2001). Cyclophosphamide induces caspase 9-dependent apoptosis in 9L tumor cells. Mol. Pharmacol. 60, 1268-1279.

SCHWARTZ, P.S., CHEN, C.S., and WAXMAN, D.J. (2002). Enhanced bystander cytotoxicity of P450 gene-directed enzyme prodrug therapy by expression of the antiapoptotic factor $\mathrm{p} 35$. Cancer Res. 62, 6928-6937.

SOSNOWSKI, B.A., GONZALEZ, A.M., CHANDLER, L.A., BUECHLER, Y.J., PIERCE, G.F., and BAIRD, A. (1996). Targeting DNA to cells with basic fibroblast growth factor (FGF2). J. Biol. Chem. 271, 33647-33653.

THERNEAU, T.M., and GRAMBSCH, P.M. (2000). Modeling Survival Data: Extending the Cox Model. (Springer-Verlag, New York).

TYMINSKI, E., LEROY, S., TERADA, K., FINKELSTEIN, D.M., HYATT, J.L., DANKS, M.K., POTTER, P.M., SAEKI, Y., and CHIOCCA, E.A. (2005). Brain tumor oncolysis with replication-conditional herpes simplex virus type 1 expressing the prodrug-activating genes, CYP2B1 and secreted human intestinal carboxylesterase, in combination with cyclophosphamide and irinotecan. Cancer Res. 65, 6850-6857.

VENABLES, W.N. (2002). Modern Applied Statistics with S (Springer-Verlag, New York).

VILE, R., ANDO, D., and KIRN, D. (2002). The oncolytic virotherapy treatment platform for cancer: Unique biological and biosafety points to consider. Cancer Gene Ther. 9, 1062-1067.

VILlANUEVA, A., GARCIA, C., PAUleS, A.B., VICENTE, M., MEGIAS, M., REYES, G., DE VILlALONGA, P., AGELL, N.,
LLUIS, F., BACHS, O., and CAPELLA, G. (1998). Disruption of the antiproliferative TGF- $\beta$ signaling pathways in human pancreatic cancer cells. Oncogene 17, 1969-1978.

WANG, W., ZHU, N.L., CHUA, J., SWENSON, S., COSTA, F.K., SCHMITMEIER, S., SOSNOWSKI, B.A., SHICHINOHE, T., KASAHARA, N., and CHEN, T.C. (2005). Retargeting of adenoviral vector using basic fibroblast growth factor ligand for malignant glioma gene therapy. J. Neurosurg. 103, 1058-1066.

WEI, M.X., TAMIYA, T., CHASE, M., BOVIATSIS, E.J., CHANG, T.K., KOWALL, N.W., HOCHBERG, F.H., WAXMAN, D.J., BREAKEFIELD, X.O., and CHIOCCA, E.A. (1994). Experimental tumor therapy in mice using the cyclophosphamide-activating cytochrome P450 2B1 gene. Hum. Gene Ther. 5, 969-978.

WEI, M.X., TAMIYA, T., RHEE, R.J., BREAKEFIELD, X.O., and CHIOCCA, E.A. (1995). Diffusible cytotoxic metabolites contribute to the in vitro bystander effect associated with the cyclophosphamide/cytochrome P450 2B1 cancer gene therapy paradigm. Clin. Cancer Res. 1, 1171-1177.

YAMAZAKI, K., NAGAO, T., YAMAGUCHI, T., SAISHO, H., and KONDO, Y. (1997). Expression of basic fibroblast growth factor (FGF-2)-associated with tumour proliferation in human pancreatic carcinoma. Virchows Arch. 431, 95-101.

\section{Address reprint requests to: Dr. Cristina Fillat Centre de Regulació Genòmica Passeig Marítim, 37-49 08003 Barcelona, Spain \\ E-mail: cristina.fillat@crg.es}

Received for publication May 5, 2006; accepted after revision October 3, 2006.

Published online: October 26, 2006. 


\section{This article has been cited by:}

1. Carmen Avendaño, J. Carlos MenéndezDrug Targeting in Anticancer Chemotherapy 595-653. [CrossRef]

2. Anabel José, Maria Rovira-Rigau, Jeroni Luna, Marta Giménez-Alejandre, Eva Vaquero, Beatriz García de la Torre, David Andreu, Ramon Alemany, Cristina Fillat. 2014. A genetic fiber modification to achieve matrix-metalloprotease-activated infectivity of oncolytic adenovirus. Journal of Controlled Release . [CrossRef]

3. Zahra Karjoo, Vidya Ganapathy, Arash HatefiGene-Directed Enzyme Prodrug Cancer Therapy 77-91. [CrossRef]

4. Jordi Martinez-Quintanilla, Deepak Bhere, Pedram Heidari, Derek He, Umar Mahmood, Khalid Shah. 2013. Therapeutic Efficacy and Fate of Bimodal Engineered Stem Cells in Malignant Brain Tumors. STEM CELLS 31:10.1002/stem.v31.8, 1706-1714. [CrossRef]

5. Matthew S. Beatty, David T. CurielAdenovirus Strategies for Tissue-Specific Targeting 39-67. [CrossRef]

6. Cristina Fillat, Anabel Jose, Xavier Bofill-DeRos, Ana Mato-Berciano, Maria Victoria Maliandi, Luciano Sobrevals. 2011. Pancreatic Cancer Gene Therapy: From Molecular Targets to Delivery Systems. Cancers 3, 368-395. [CrossRef]

7. Anabel José, Luciano Sobrevals, Antoni Ivorra, Cristina Fillat. 2011. Irreversible electroporation shows efficacy against pancreatic carcinoma without systemic toxicity in mouse models. Cancer Letters . [CrossRef]

8. Daniel Abate-Daga, Laura Garcia-Rodríguez, Lauro Sumoy, Cristina Fillat. 2010. Cell cycle control pathways act as conditioning factors for TK/GCV sensitivity in pancreatic cancer cells. Biochimica et Biophysica Acta (BBA) - Molecular Cell Research 1803, 1175-1185. [CrossRef]

9. T J Harvey, D Burdon, L Steele, N Ingram, G D Hall, P J Selby, R G Vile, P A Cooper, S D Shnyder, J D Chester. 2010. Retargeted adenoviral cancer gene therapy for tumour cells overexpressing epidermal growth factor receptor or urokinase-type plasminogen activator receptor. Gene Therapy 17, 1000-1010. [CrossRef]

10. Meritxell Huch, Alena Gros, Anabel José, Juan Ramon González, Ramon Alemany, Cristina Fillat. 2009. Urokinase-Type Plasminogen Activator Receptor Transcriptionally Controlled Adenoviruses Eradicate Pancreatic Tumors and Liver Metastasis in Mouse Models. Neoplasia 11, 518-IN6. [CrossRef] 